\title{
Agronomic and bromatological responses of white and black oats to triple superphosphate and magnesium thermophosphate
}

\author{
Fernanda Aparecida Beira ${ }^{1} \odot$, Juliano Cesar Dias ${ }^{1 *} \odot$, Henrique von Hertwig Bittencourt ${ }^{1} \odot$, \\ Lisandro Tomas da Silva Bonome ${ }^{1}$ (1)

\footnotetext{
${ }^{1}$ Universidade Federal da Fronteira Sul, Laranjeiras do Sul, PR, Brasil. E-mail: fernanda_beira@hotmail.com; julianocdias@yahoo.com.br; henrique.bittencourt@uffs.edu.br; lisandro.bonome@uffs.edu.br
}

ABSTRACT: The objective of this work was to evaluate the effects of triple superphosphate, magnesium thermophosphate and their mixtures in the agronomic and bromatological characteristics of black and white oats. The experiment was conducted in a $2 \times 6$ factorial scheme, constituted by the two forages: black and white oats; and two sources of phosphorus (P): triple superphosphate and magnesium thermophosphate, at a dose of $70 \mathrm{~kg} \mathrm{ha}^{-1}$ of $\mathrm{P}_{2} \mathrm{O}_{5}$, in the proportions: 0:0, 100:0, 0:100, 50:50, $75: 25$ and $25: 75$. The effect of fertilization and $P$ source on the total dry matter of black and white oats $(p<0.05)$ ranged from $0.21 \pm 0.03$ to $10.83 \pm 0.33$ and from $0.14 \pm 0.00$ to $13.79 \pm 0.60 \mathrm{~g} \mathrm{pot}^{-1}$, respectively. Greater forage production was observed in black and white oats fertilized with triple superphosphate $(p<0.05)$, even when used in a mixture up to $50 \%$. Due to the different responses observed and the variation in the levels of $\mathrm{P}$ and crude protein in the forages, it was not possible to determine the effect of the fertilization and the sources of $P$ in these variables. It was verified that black and white oats presented better responses in their productive characteristics when submitted to triple superphosphate source and 50:50, 75:25, and 25:75 mixtures than when submitted to magnesium thermophosphate.

Key words: Avena spp.; forage production; phosphorus fertilization; plant nutrition

\section{Respostas agronômicas e bromatológicas das aveias branca e preta ao superfosfato triplo e termofosfato magnesiano}

RESUMO: O objetivo do trabalho foi avaliar os efeitos da aplicação de superfosfato triplo, termofosfato magnesiano e suas misturas nas características agronômicas e bromatológicas das aveias preta e branca. $\mathrm{O}$ experimento foi conduzido em um esquema fatorial $2 \times 6$, constituído por duas forrageiras: aveias preta e branca; e duas fontes de fósforo $(\mathrm{P})$ : superfosfato triplo e termofosfato magnesiano, na dose de $70 \mathrm{~kg} \mathrm{ha}^{-1}$ de $\mathrm{P}_{2} \mathrm{O}_{5}$, nas proporções: 0:0, 100:0, 0:100, 50:50, 75:25 e 25:75. Observou-se efeito da adubação e da fonte de $P$ na produção de matéria seca total das aveias preta e branca $(p<0,05)$ que variaram de 0,21 $\pm 0,03$ a 10,83 $\pm 0,33$ e de $0,14 \pm 0,00$ a $13,79 \pm 0,60 \mathrm{~g}$ vaso- $^{-1}$, respectivamente. Constatou-se maior produção forrageira nas aveias preta e branca adubadas com superfosfato triplo $(p<0,05)$, mesmo quando utilizado em mistura até $50 \%$. Em função das diferentes respostas observadas e da variação nos teores de $\mathrm{P}$ e de proteína bruta nas forrageiras, não foi possível determinar 0 efeito da adubação e das fontes de $P$ nestas variáveis. Verificou-se que as aveias preta e branca apresentam melhores respostas produtivas ao serem submetidas ao superfosfato triplo e suas misturas 50:50, 75:25 e 25:75 do que quando submetidas ao termofosfato magnesiano.

Palavras-chave: Avena spp.; adubação fosfatada; produção de forragem; nutrição vegetal

\footnotetext{
* Juliano Cesar Dias - E-mail: julianocdias@yahoo.com.br (Corresponding author)

Associate Editor: Márcio Vieira da Cunha
} 


\section{Introduction}

In Brazil, grasses are of great importance in the feeding of ruminants, forming the basis of the diet of dairy and beef cattle. Due to the climatic characteristics and territorial extension of the country, they are still the most economical and practical way to produce food for cattle (Dias-Filho, 2014). However, the low productivity of Brazilian pastures decreases the profitability and competitiveness of production systems, highlighting the characteristic of concentration of production in the spring-summer period and scarcity in the autumnwinter period (Zamarchi et al., 2014).

Currently, several forage species can be used in the winter period. Among them, black oats (Avena strigosa Schreb) and white oats (Avena sativa L.) are used by farmers for presenting productive and nutritional characteristics interesting for extensive production systems. These two species differ in relation to the vegetative cycle, with white oat having a longer cycle than black oat (Prado et al., 2006).

Another limitation for Brazilian cattle ranching lies in low forage production, generally caused by the gradual decrease in soil fertility. Brazil has approximately 100 million hectares of pastures that present some stage of degradation (Dias-Filho, 2014), corresponding to up to $70 \%$ of the entire area destined for this activity. Thus, the use of fertilizers and agricultural correctives is a decisive factor in increasing the productivity of forage crops with the potential to respond to the application of fertilizers (Parreira et al., 2015).

Phosphorus $(P)$ is the most limiting nutrient for biomass productivity in tropical soils (Maranguit et al., 2017), interfering with the establishment and the dry matter production of pastures (Carneiro et al., 2017; Costa et al., 2017). Most of the phosphorus applied to the soil is unavailable to plants because it remains retained in the solid phase, forming less soluble compounds (Saldanha et al., 2017). Thus, care should be doubled with the sources and dosage, since phosphorus limitation can also interfere with the response to nitrogen by reducing nitrate uptake rates, and the spatial separation of nutrients can cause less accumulation of these minerals in the aboveground part of the plant (Silva et al., 2009), thus impairing forage production.

To minimize this effect in base dressings, $P$ is generally supplied to the plants in the form of soluble phosphates, which limits the dose applied due to cost (Ono et al., 2009). The application of phosphorus sources with high solubility together with alternative sources, with lower solubility and cost, can be a way to improve the efficiency of less soluble sources, such as reactive phosphates (Cabral et al., 2015; Pereira et al., 2018).

Therefore, part of the phosphorus is supplied in soluble form and readily available for immediate use by the plant, while the other phosphorus fraction remains in the soil to be solubilized later, minimizing fixation and providing a residual effect of this nutrient (Cabral et al., 2015).

The present work aims to evaluate the effects of the application of triple superphosphate, magnesium thermophosphate, and their mixtures on forage production, agronomic characteristics, and phosphorus availability in black (Avena strigosa Schreb) and white oats (Avena sativa L.).

\section{Materials and Methods}

The experiment was conducted in the greenhouse of the Federal University of Fronteira Sul - Laranjeiras do Sul (UFFS) campus, between July and October 2017, located at $25^{\circ} 26^{\prime} 40.94^{\prime \prime} \mathrm{S}$ and $52^{\circ} 26^{\prime} 16.63^{\prime \prime} \mathrm{W}$ and $803 \mathrm{~m}$ altitude.

The experimental design used was entirely randomized with three repetitions in a $2 \times 6$ factorial scheme. We used Avena strigosa Schreb (black oat cv. IAPAR 61 Ibiporã) and Avena sativa L. (white oat cv. IPR Suprema) as forage crops, and triple superphosphate (TSP - 41\% $\mathrm{P}_{2} \mathrm{O}_{5}$ ) and magnesium thermophosphate (MTP - 17.5\% $\mathrm{P}_{2} \mathrm{O}_{5}$ ) powder at a dose of 70 $\mathrm{kg} \mathrm{ha}^{-1}$ of $\mathrm{P}_{2} \mathrm{O}_{5}$ as sources of phosphorus $(\mathrm{P})$ in six different ratios: 0:0, 100:0, 0:100, 50:50, 75:25, and 25:75 for the TSP and MTP sources, respectively.

The soil used in the study, classified as Red Latosol dystrophic, medium texture, was collected from the superficial layer $(0$ to $20 \mathrm{~cm}$ ) in the experimental area of UFFS, and presented the following chemical characteristics: $38.1 \mathrm{~g}$ $\mathrm{dm}^{-3}$ of organic matter (O.M.); $2.7 \mathrm{mg} \mathrm{dm}^{-3}$ of $\mathrm{P} ; 0.05 \mathrm{cmol}$

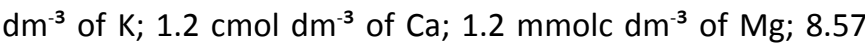
$\mathrm{cmol} \mathrm{dm}^{-3}$ of $\mathrm{H}+\mathrm{Al}$ and 4.2 of $\mathrm{pH}$ in $\mathrm{CaCl} 2 ; 2.48 \mathrm{cmol} \mathrm{dm}^{-3}$ of sum of bases (SB); $11.7 \mathrm{cmol} \mathrm{dm}^{-3}$ of cation exchange capacity (CEC); $22.4 \% \mathrm{~V}$ and $0.37 \mathrm{mg} \mathrm{dm}^{-3}$ of $\mathrm{B} ; 2.8 \mathrm{mg} \mathrm{dm}^{-3}$ of $\mathrm{Cu} ; 70.3$ of $\mathrm{mg} \mathrm{dm}^{-3} \mathrm{Fe} ; 362.0 \mathrm{mg} \mathrm{dm}^{-3}$ of $\mathrm{Mn}$; and $0.9 \mathrm{mg} \mathrm{dm}^{-3}$ of $\mathrm{Zn}$. To correct acidity, calcareous limestone (PRNT $=89 \%$ ) was used to raise the $\mathrm{V} \%$ to $60 \%$. After collection, the soil was crushed, sieved with a $4 \mathrm{~mm}$ mesh, and transferred to the pots. The base fertilization was performed with potassium chloride at a dose of $101.4 \mathrm{~kg} \mathrm{ha}^{-1}$; for the nitrogen fertilization, urea was used at a dose of $300 \mathrm{~kg} \mathrm{ha}^{-1}$, divided into two applications, the first 16 days after emergence (DAE) and the second 47 DAE.

Sowing occurred on 07/03/2017, using 20 seeds per pot placed $3 \mathrm{~cm}$ deep. After full emergence, the plants were thinned, leaving 8 plants per pot, and then cut to uniform the plants. At 47 DAE the first cut was made, with the second and third cuts made at 28-day intervals, at a cutting height of $5 \mathrm{~cm}$ from the ground.

The temperature of the greenhouse was maintained between 15 and $22{ }^{\circ} \mathrm{C}$. Irrigation was performed by automatic sprinkler activation, totaling $4.5 \mathrm{~mm} \mathrm{day}^{-1}$, with additional irrigation of $100 \mathrm{~mL}$ vase $^{-1}$ when the soil presented a dry aspect.

The height of the plants and the chlorophyll content (chlorophyllometer - model CFL1030) were measured before the cuts were made. After the first cut, the chlorophyll content was evaluated weekly, always on the leaf below the flag leaf on all plants in the pot, calculating an average of the readings. Moreover, at the time of cutting, the number of plants per pot and the number of tillers per plant were verified. After cutting, the leaf area (leaf area meter - model Cl-203CA Conveyor Attachment) and the number of leaves per plant 
were checked. Subsequently, the aerial part was separated into leaf and stem (stem + sheath), dried in an air oven at $65^{\circ} \mathrm{C}$ for 72 hours and the dry matter (DM) was determined. After the third cut, the soil was carefully removed from the pots, placed on a $5 \mathrm{~mm}$ mesh sieve, and washed in running water to obtain the roots, which were dried to determine the root DM.

The $P$ content in the aerial part was verified from $2 \mathrm{~g}$ samples of plant tissue used for ash determination, obtained after remaining in a muffle furnace at $550{ }^{\circ} \mathrm{C}$ for 2 hours. 10 $\mathrm{mL}$ of distilled water, $5 \mathrm{~mL}$ of concentrated hydrochloric acid, and 5 drops of nitric acid were added to the ash, with heating at $105^{\circ} \mathrm{C}$ until evaporation of half of the initial volume, and then completed with distilled water up to $100 \mathrm{~mL}$ (mineral solution). The reagent solution, called stained reagent, was prepared by adding $20 \mathrm{~g}$ of ammonium molybdate in 350 $\mathrm{mL}$ of boiling water (solution A). Next, $1 \mathrm{~g}$ of ammonium metavanadate was added to $300 \mathrm{~mL}$ of boiling water, with stirring until complete dissolution; after cooling, $160 \mathrm{~mL}$ of concentrated nitric acid was added (solution B). The solutions were mixed and diluted with distilled water to $1000 \mathrm{~mL}$. In a colorimeter tube, $5 \mathrm{~mL}$ of the mineral solution and $5 \mathrm{~mL}$ of the stained reagent were added, mixed well, then rested for 10 minutes and read in a colorimeter at $420 \mathrm{~nm}$. A standard solution with a concentration of $50 \mathrm{ppm}$ of phosphorus was made from $\mathrm{KH}_{2} \mathrm{PO}_{4}$ to prepare the standard curve with concentrations from 0.0 to $12.5 \mathrm{ppm}$ of $\mathrm{P}$; the phosphorus of the samples was determined from the standard curve (Prates, 2007). The crude protein (CP) was determined by the Kjeldahl method.

Data were submitted to factorial analysis of variance (ANOVA) and means were compared by Duncan's test at $5 \%$ probability using the Genes statistical computer application. Data distribution was verified by Levene's homogeneity and Lilliefors' normality tests using logarithmic transformation $[\log (X+1)]$ for data normalization, when necessary. Pearson's correlation test was applied to verify association between root dry matter (RDM), total dry matter (TDM), and leaf dry matter (LDM).

\section{Results and Discussion}

Mean total DM yields ranged from $0.21 \pm 0.03$ to $10.83 \pm 0.33$ $\mathrm{g} \mathrm{pot}^{-1}$ in black oats, and from $0.14 \pm 0.00$ to $13.79 \pm 0.60 \mathrm{~g} \mathrm{pot}^{-1}$ in white oats, with an interaction effect between phosphate fertilization and oat species $(p<0.05)$ on forage production (Figure 1).

The highest values of TDM and LDM were recorded, in most cases, with the TSP source in relation to the MTP source. This was also true for the mixture of sources in the proportions of 75:25 and 50:50 of TSP and MTP, respectively. This result agrees with that reported by Santos (2004), who found higher average DM production with the use of TSP compared to fertilization with Arad reactive phosphate and natural phosphate from Araxá.

It was possible to verify the superiority of TSP over MTP in the forage production of black and white oats, even
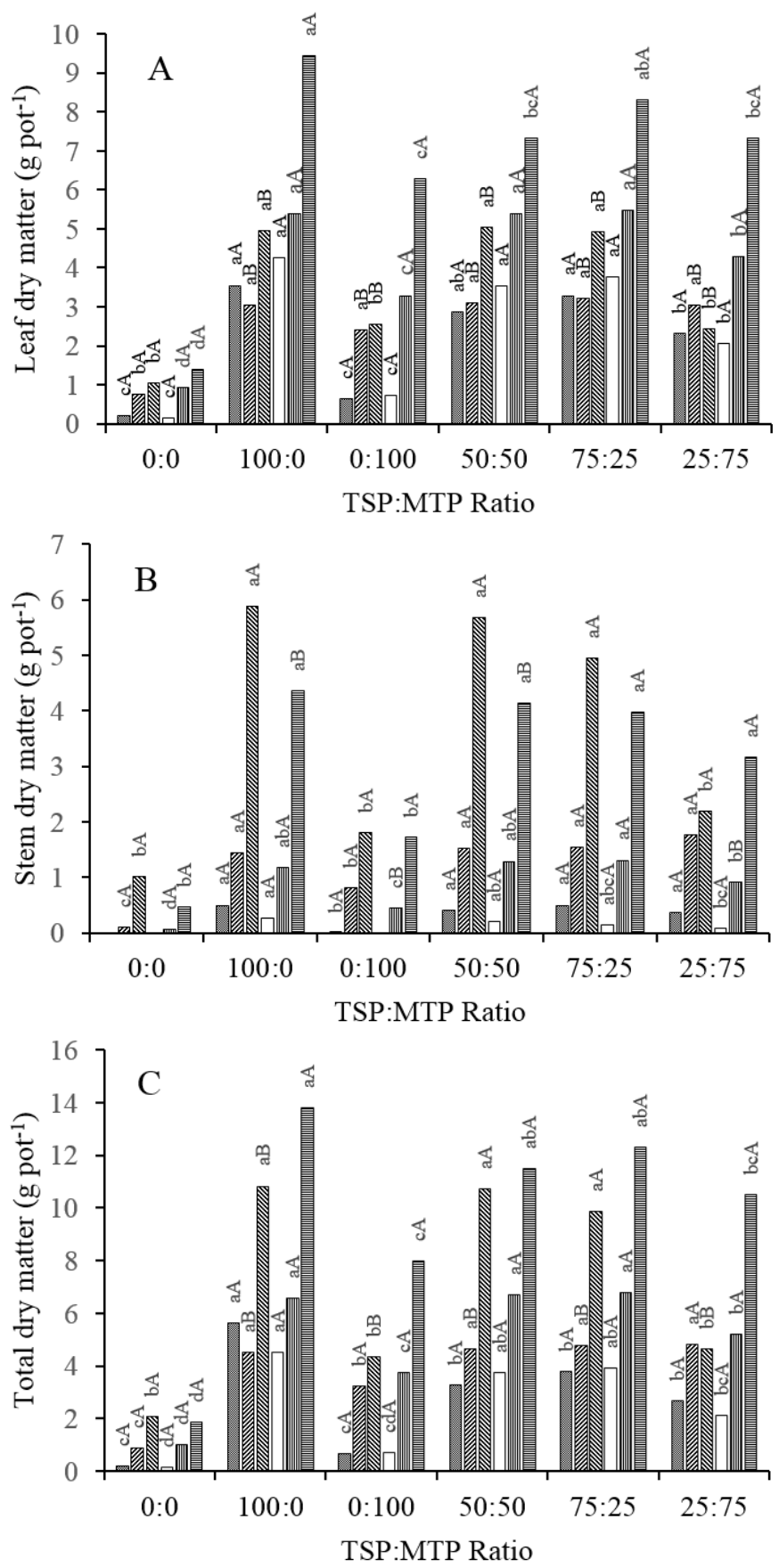

$\square$ Black oat 1 st cut Black oat 2 nd cut $\mathbb{\mathbb { B }}$ Black oat 3rd cut

$\square$ White oat 1st cut $\mathbf{m}$ White oat 2nd cut 国 White oat 3rd cut

NOTE: Columns with the same lower-case letter do not differ between TSP:MTP ratios of the same species, and with the same upper-case letter, they do not differ between species in the same cut by Duncan's test $(p>0.05)$.

Figure 1. Production of leaf dry matter (A), stem dry matter (B), and total dry matter (C) of Avena strigosa cv. IPR 61 and Avena sativa CV. IPR Suprema as a function of phosphate fertilization with triple superphosphate (TSP) and magnesium thermophosphate (MTP).

when used in mixture up to $50 \%$ of TSP. This was similar to that observed by Ono et al. (2009), for TSP and Arad natural phosphate in soybean fertilization. This observation reinforces the importance of considering the $P$ source to predict its 
availability for the crop species, because $P$ doses are generally calculated based only on the total $\mathrm{P}_{2} \mathrm{O}_{5}$ concentration of the source used (Ono et al., 2009).

Overall, white oats showed higher DM production in the first, second and third cuts when compared to black oats; diverging from Fontaneli et al. (2012) and Cherubin et al. (2014). The contradictory results observed regarding differences in the DM production of black and white oats may be related to differences between the cultivars of black and white oats used in the work, as well as differences in environmental aspects, such as temperature, humidity, rainfall, and radiation.

There was an interaction $(p<0.05)$ between $P$ source and forage used for the root system dry matter variable (Figure 2 ). The TSP source alone and the mixtures in the proportions 75:25 and 50:50 of TSP and MTP, respectively, provided greater accumulation of root dry matter in black oats. For white oats, the TSP and MTP mixtures in the proportions 50:50 and 75:25, respectively, provided the greatest accumulation of root dry matter.

The results found are different from those observed by Rezende et al. (2011), who found no differences between treatments with phosphate fertilization in root length and RDM but found that $P$ restriction caused greater root length and lower RDM.

MTP produced lower yields of RDM, presumably because the source was less soluble for oats. This fact is justified because the availability of $\mathrm{P}$ for root development behaves differently and depends on the solubility of this nutrient, which varies according to the source. The more water-soluble phosphates are more efficient if applied close to the roots, whereas natural phosphates need more fertilizer-soil contact in order to have maximum absorption efficiency by the plant (Santos, 2004).

$P$ plays an important role in crop establishment, affecting the production of aboveground and root DM (Rezende et al.,

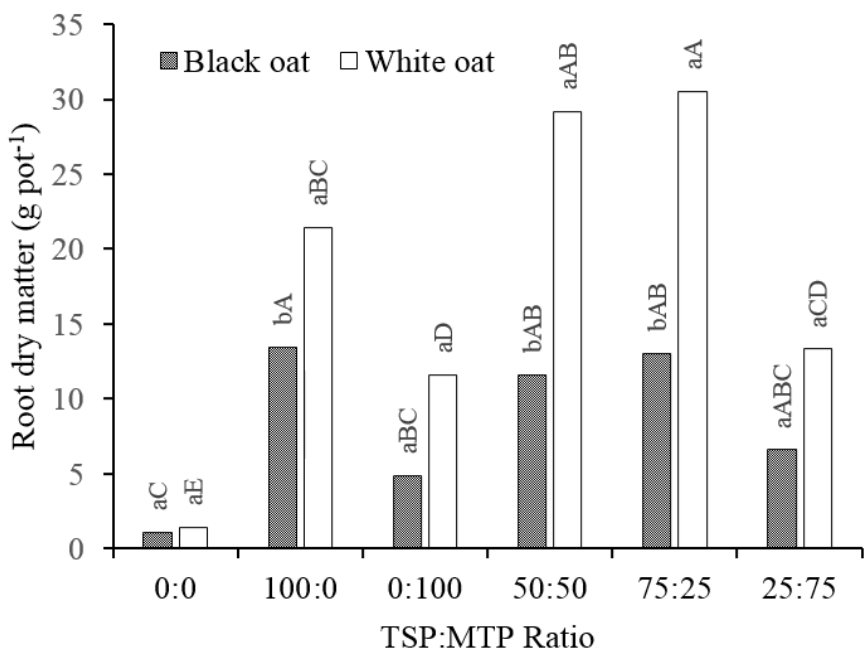

NOTE: Columns with the same capital letter do not differ between TSP:MTP ratios of the same species, and with the same lower-case letter, they do not differ between species in the same ratio of phosphorus sources by Duncan's test $(p>0.05)$.

Figure 2. Dry matter of the root system of Avena strigosa cv. IPR 61 and Avena sativa cv. IPR Suprema due to phosphate fertilization with triple superphosphate (TSP) and magnesium thermophosphate (MTP).
2011), affecting crop establishment. According to Prado et al. (2006), the highest DM productions of the aboveground part and root for black oat occurred when $\mathrm{P}$ concentration in the soil was close to $100 \mathrm{mg} \mathrm{dm}^{-3}$; different from that verified by Bonfim-Silva et al. (2012), who found a gradual increase in RDM production until the dose of $250 \mathrm{mg} \mathrm{dm}^{-3}$.

Phosphorus is an integral component of important metabolic and structural compounds in plant cells, acting in cell signaling, transport, and transduction of substrates and chemical energy (Primavesi \& Primavesi, 2018; Taiz et al., 2017). Therefore, $P$ availability favors plant growth and development, a fact that can justify the higher yield of oat RDM in the treatments with isolated source and in the mixtures with the presence of TSP, since it is more available to plants, due to its high solubility in water and low residual effect (Dias et al., 2017).

There was a correlation of $0.88(p<0.01)$ between RDM and LDM, suggesting a link between forage production and root production, which was also found by Oliveira et al. (2016) in rice crop. Phosphorus also played an important role in the tillering and growth of the root system, stem and leaves of Panicum maximum, key characteristics for higher forage productivity (Melo et al., 2018).

There was an effect $(p<0.05)$ of the interaction of phosphate fertilization with the two oat species on the number of tillers per plant and leaves per plant (Figure 3).

It was found that the TSP source was superior to the MTP source in most evaluations for the number of tillers and leaves per plant, a fact also noted for the mixtures between the sources in the proportions of 75:25 and 50:50 of TSP and MTP, respectively. In the third cutting, white oats also responded to the 25:75 mixture of TSP and MTP, respectively. MTP is less soluble than TSP in soil and is soluble only in $2 \%$ citric acid. Thus, the slower release of phosphorus to the plant by MTP compared to the TSP source may have contributed to the lower number of tillers and leaves per plant.

In the establishment phase of pastures, tillering plays an important role, especially when plants undergo removal of the apical meristem. In this situation the tillers ensure regrowth and, consequently, the production and longevity of the pasture (Bortolini et al., 2004; Duchini et al., 2016). Gradual increase in the number of tillers occurs by breaking apical dominance, which allows developing lateral buds that were previously dormant.

Besides the stimulating effect of cutting on tillering, Bonfim-Silva et al. (2012) associated the increase in the number of leaves and tillers with $\mathrm{P}$ availability in the soil, a result similar to that observed in this study. However, Costa et al. (2017), working with Mombasa grass, found that doses higher than $120 \mathrm{~kg} \mathrm{ha}^{-1}$ of $\mathrm{P}_{2} \mathrm{O}_{5}$ decreased the number of leaves per tiller.

The number of tillers and leaves is the product of the relationship between the genetic characteristics of the plant with environmental factors that influence photoassimilate production (Pimentel et al., 2016). This may justify the higher production of tillers and leaves per plant in the treatments with the presence of TSP. 

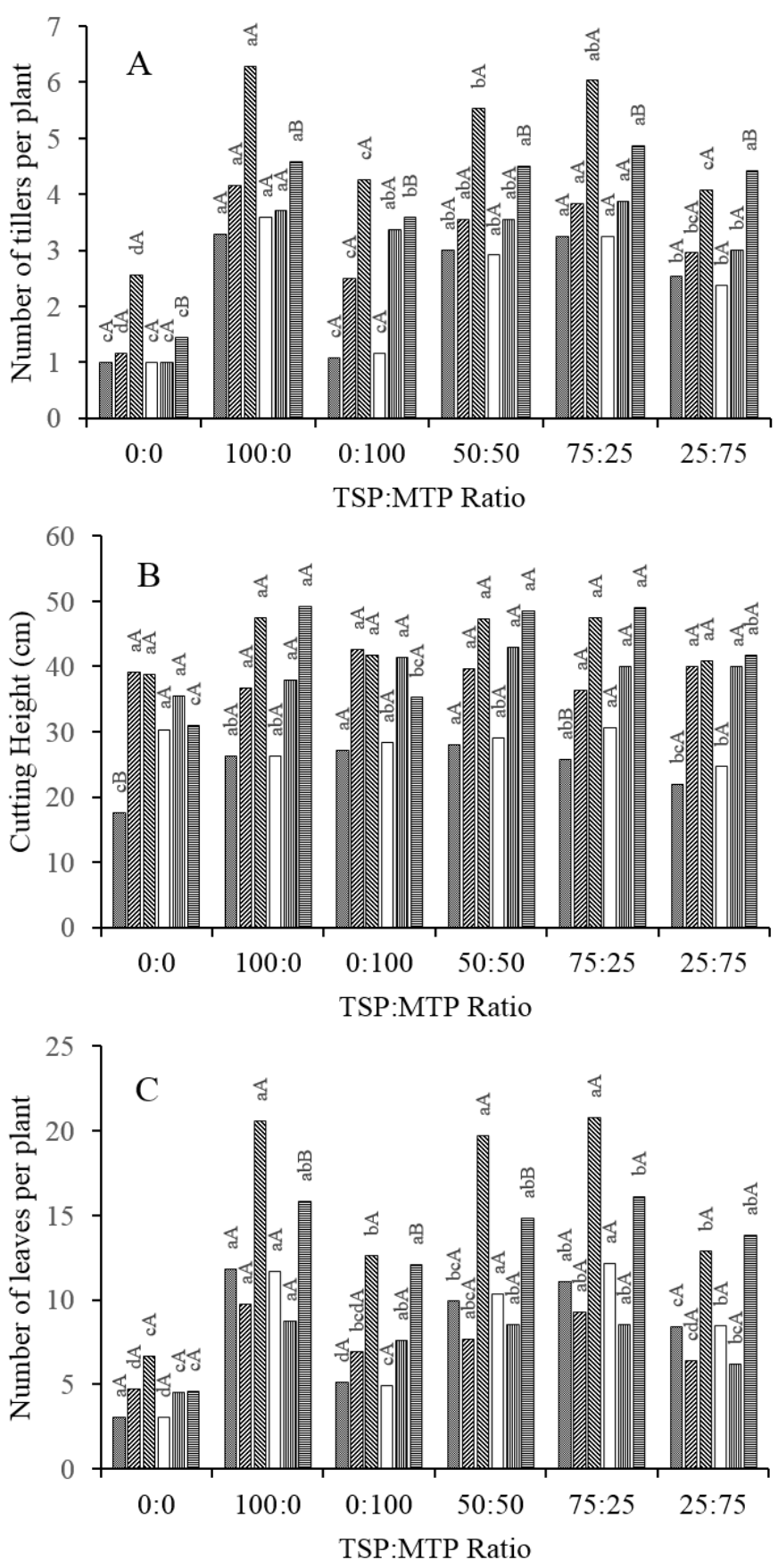

$\square$ Black oat 1st cut Black oat 2 nd cut $\mathbb{N}$ Black oat 3rd cut

$\square$ White oat 1 st cut $\mathbf{m}$ White oat 2nd cut 自 White oat 3rd cut NOTE: Columns with the same lower-case letter do not differ between TSP:MTP ratios of the same species, and with the same upper-case letter, they do not differ between species in the same cut by Duncan's test $(p>0.05)$.

Figure 3. Number of tillers per plant $(A)$, cutting height (B), and number of leaves per plant (C) of Avena strigosa cV. IPR 61 and Avena sativa cV. IPR Suprema as a function of phosphate fertilization with triple superphosphate (TSP) and magnesium thermophosphate (MTP).

Regarding the cutting height, it was found that the forages had different behaviors between cuts (Figure 3 ). In the first cut, the effect of fertilizer and $P$ source on the cutting height of black oats was observed, with the TSP:MTP treatment in the proportion 25:75 and the control group $\left(0 \% \mathrm{P}_{2} \mathrm{O}_{5}\right)$ not differing from each other $(p>0.05)$; the control group was the only treatment to differ from the other groups evaluated. As for white oats, greater cutting height was observed $(p<0.05)$ in the treatments 100:0, 75:25, and 50:50 in the proportions of the mixtures between TSP and MTP, respectively.

It was also found that when the P source was MTP alone, the cutting height did not differ $(p>0.05)$ from the control group (0\% P2O5), and that both showed lower cutting height $(p<0.05)$ than the treatment where the $P$ source was restricted to TSP.

Prado et al. (2006) and Rezende et al. (2011) also found that phosphate fertilization affects forage cutting height, with greater cutting height of plants that received $\mathrm{P}$ fertilizer compared to those that did not.

Bonfim-Silva et al. (2012), working with Marandu grass, observed an increase in cutting height between the first and second cuts, results similar to those found in this work. This fact may have occurred because the plants had already established their root system, thus providing a greater input of carbohydrates and mineral nutrients for reestablishing the plants.

In addition, a more developed root system provides greater contact with the mineral nutrients available in the soil, especially phosphorus, allowing greater absorption, benefiting the plant in growth and forage production (Bonfim-Silva et al., 2012). These questions are strictly related to the tiller production, number of leaves, and cutting height ascertained in the experiment.

There was no effect $(p>0.05)$ of fertilization and $P$ source on the number of plants per pot in the two forage species evaluated, with means \pm standard errors ranging from $7.66 \pm$ 0.33 to $8.00 \pm 0.00$ plants.

There was a fertilization and $P$ source effect $(p<0.05)$ on the leaf area in black and white oats in the first and third cuts evaluated, with a greater response when working with TSP, the same in the different proportions evaluated (Figure 4).

The leaf area (LA) suffered great variation between cuts and in the treatment with $0.0 \% \mathrm{P}_{2} \mathrm{O}_{5}$; these results differ from Cruz et al. (2009), who, when evaluating two grain sorghum hybrids subjected to four doses of phosphorus $(0,25,50$, and $75 \mathrm{~kg} \mathrm{ha}^{-1}$ ), found a directly proportional response between the $P$ dose and LA, with the concentration of $0 \mathrm{~kg} \mathrm{ha}^{-1}$ of $P$ keeping LA stable throughout the evaluation period.

Costa et al. (2017) found an increase in LA and number of tillers when Mombasa grass was subjected to doses of 0; 30; 60 ; and $90 \mathrm{~kg} \mathrm{ha}^{-1}$ of $\mathrm{P}_{2} \mathrm{O}_{5}$ but reduced at the dose of $120 \mathrm{~kg}$ ha-1 of $\mathrm{P}_{2} \mathrm{O}_{5}$.

Phosphorus integrates molecules essential to plant metabolism; moreover, it increases the efficiency of absorbed nitrogen, which is assimilated into organic compounds, increasing the formation of new tissues. This allows for an increase in both leaf area and the longevity of photosynthetically active leaves, which under favorable environmental conditions promote the efficient use of solar radiation, increasing the accumulation of dry matter and grain production (Cruz et al., 2009). 

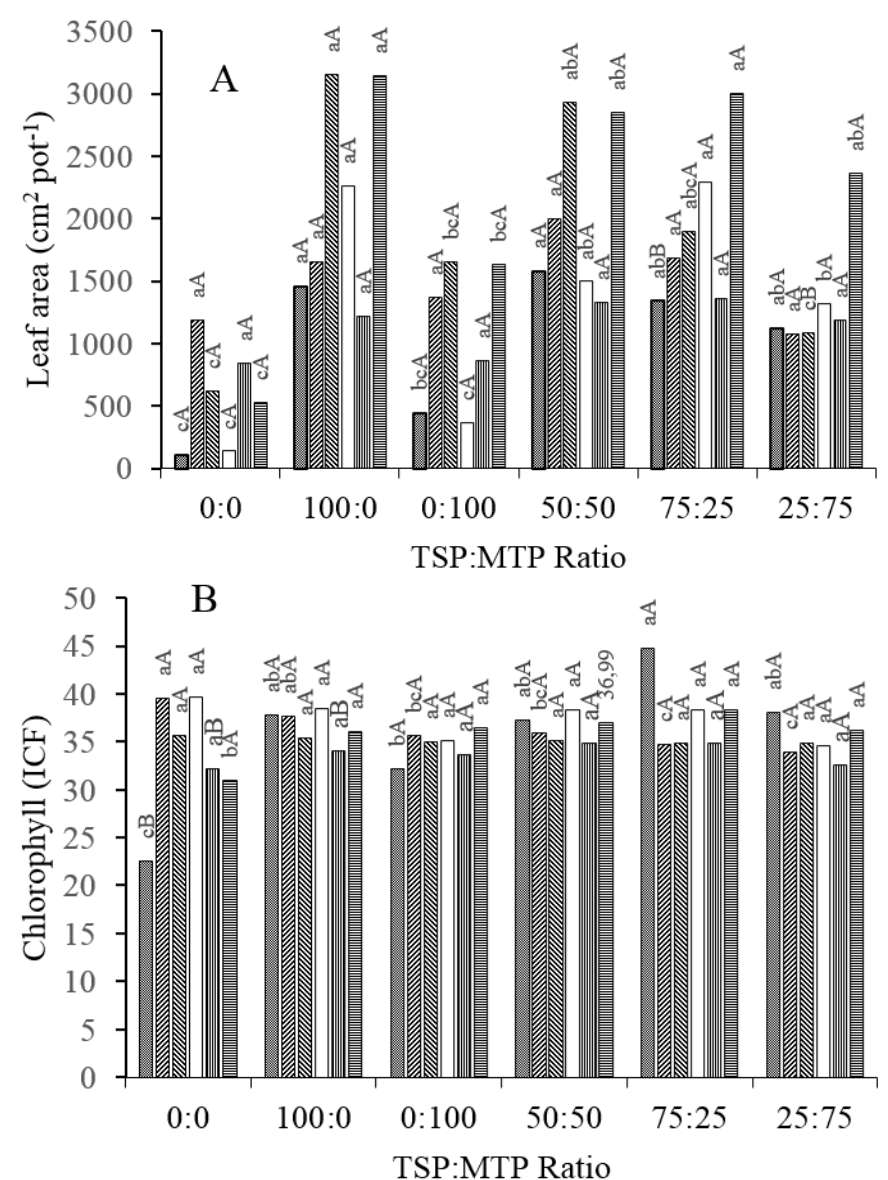

$\square$ Black oat 1 st cut $\mathbb{Z}$ Black oat 2 nd cut $\mathbb{\mathbb { B }}$ Black oat 3 rd cut

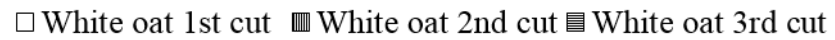

NOTE: Columns with the same lower-case letter do not differ between TSP:MTP ratios of the same species, and with the same upper-case letter, they do not differ between species in the same cut by Duncan's test ( $p>0.05)$.

Figure 4. Leaf area (A) and chlorophyll content (B) of Avena strigosa cV. IPR 61 and Avena sativa cv. IPR Suprema due to phosphate fertilization with triple superphosphate (TSP) and magnesium thermophosphate (MTP).

Regarding the chlorophyll content in the leaf (Figure 4), the effect of phosphate fertilization $(p<0.05)$ was found only in the third cut for white oats, with no effect of the source of $P$ used $(p>0.05)$, with all treatments showing higher chlorophyll concentration than the treatment without phosphate fertilization. For black oats, there was a fertilization and $P$ source effect $(p<0.05)$ on chlorophyll content in the first cut, with the treatments that had TSP as a P source, either isolated or in different proportions mixed with MTP, showing the highest leaf chlorophyll contents.

There was no significant difference in chlorophyll content between black and white oats, which corroborates Wolff \& Floss (2008), when subjecting white oat cultivars to a dose of $50 \mathrm{~kg} \mathrm{ha}^{-1}$ of $\mathrm{P}_{2} \mathrm{O}_{5}$.

The $\mathrm{P}$ doses did not influence the chlorophyll content, diverging from Manarin (2005), who found a strong interaction of $\mathrm{P}$ and zinc doses with leaf chlorophyll content, resulting in mean chlorophyll values of approximately $20 \mu \mathrm{g} \mathrm{mL}^{-1}$ for Tanzania grass.
Figure 5 shows the levels of $P$ and crude protein (CP) in black and white oats as a function of phosphate fertilization management. Due to the different responses observed and the variation in $\mathrm{P}$ levels in the different cuts, it was not possible to evaluate the effect of fertilization and $P$ sources on the concentration of this mineral in the aboveground part of the forages studied.

Similar values in plant $P$ contents were found by Prado et al. (2006), who observed an increase in leaf $P$ content with the increase in the dose of $\mathrm{P}$ made available when the dose of $\mathrm{N}$ was $100 \mathrm{mg} \mathrm{dm}^{-3}$; however, when the dose was $300 \mathrm{mg} \mathrm{dm}^{-3}$ of $\mathrm{N}$, a reduction in plant $\mathrm{P}$ was observed.

$P$ increased uptake and transport in the plant can be explained by the concentration of $\mathrm{N}$, because for $\mathrm{N}$ assimilation into organic compounds, reduction reactions occur that involve ATP expenditure and the transfer of electrons NAD(P)
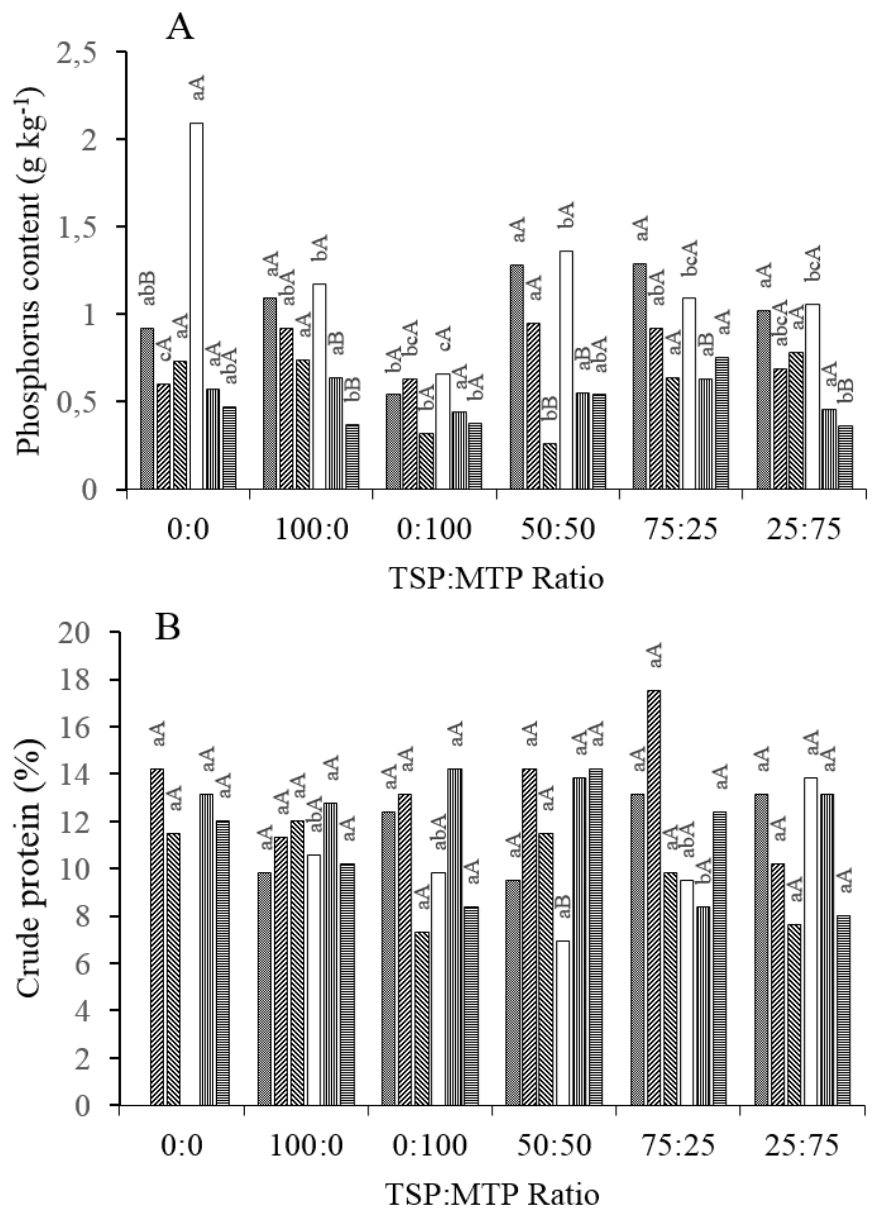

\section{$\square$ Black oat 1 st cut Black oat 2 nd cut $\mathbb{Q}$ Black oat 3rd cut}

$\square$ White oat 1 st cut $\mathbf{m}$ White oat 2 nd cut 自 White oat 3rd cut NOTE: Columns with the same lower-case letter do not differ between TSP:MTP ratios of the same species, and with the same upper-case letter, they do not differ between species in the same cut by Duncan's test $(p>0.05)$.

Figure 5. Phosphorus (A) and crude protein (B) contents in the dry matter of the aerial part of Avena strigosa cv. IPR 61 and Avena sativa cv. IPR Suprema as a function of phosphate fertilization with triple superphosphate (TSP) and magnesium thermophosphate (MTP). 
and $\mathrm{NAD}(\mathrm{P}) \mathrm{H}$, which have $\mathrm{P}$ in their structures (Taiz et al., 2017). According to Long et al. (2015), more than $25 \%$ of the energy from photosynthesis is directed to nitrate assimilation.

It is assumed that the decrease in aerial part $P$ concentration in the different cuts is due to the decrease in available P in the soil. Nakagawa \& Rosolem (2005) found no increase in the availability of $P$ in the flag leaf and oat grain with increasing $P$ dose.

BP levels were not affected $(p>0.05)$ by phosphate fertilization in black oats. In white oats, the characteristics of the response to fertilization and the source of $P$ in the first cut, and the absence of difference observed ( $p>0.05$ ) in subsequent cuts, also allow us to state that phosphate fertilization did not affect the levels of CP in white oats in this study, a fact similar to that found by Jat et al. (2014).

PB (\%) results ranged from $7.29 \pm 0.96$ to $17.50 \pm 1.67$ in black oats, and from $6.92 \pm 0.36$ to $14.21 \pm 2.18$ in white oats, thus being similar to those verified by Jat et al. (2014) and Luikham et al. (2015), but lower than those described by Primavesi et al. (2000) and Joshi et al. (2015) for white oats.

\section{Conclusions}

Black and white oats respond to phosphate fertilization with triple superphosphate and magnesium thermophosphate; however, the best responses in their productive characteristics are obtained with triple superphosphate fertilization.

The phosphorus and crude protein content of the aboveground part of the plant are not influenced by phosphate fertilization in black and white oats.

The mixture of magnesium thermophosphate and triple superphosphate performs better than using magnesium thermophosphate alone.

\section{Compliance with Ethical Standards}

Author contributions: Conceptualization: FAB, JCD; Data curation: $F A B, J C D$; Formal analysis: $F A B, H v H B$; Investigation: $F A B$, JCD, HvHB; Methodology: FAB, JCD, HvHB; Project administration: FAB, JCD; Resources: FAB, JCD, HvHB, LTSB; Supervision: FAB, JCD; Validation: FAB, JCD, HvHB, LTSB; Visualization: FAB, JCD, HvHB, LTSB; Writing - original draft: FAB, JCD, HvHB, LTSB; Writing - review \& editing: JCD, HvHB; LTSB.

Conflict of interest: The authors declare that there is no conflict of interest.

Financing source: This work has no financial funding.

\section{Literature Cited}

Bonfim-Silva, E.M.; Santos, C.C.; Farias, L.N.; Vilarinho, M.K.C.; Guimarães, S.L.; Silva, T.J.A. Características morfológicas e produtivas do capim-marandu adubado com fosfato natural reativo em solo de cerrado. Revista Agro@mbiente, v.6, n.2, p.166-171, 2012. https://doi.org/10.18227/190ragro.v6i2.756.
Bortolini, P.C.; Sandini, I.; Carvalho, P.C.F.; Moraes, A. Cereais de inverno submetidos ao corte no sistema de duplo propósito. Revista Brasileira de Zootecnia, v.33, n.1, p.45-50, 2004. https:// doi.org/10.1590/S1516-35982004000100007.

Cabral, C.E.A.; Cabral, L.S.; Bonfim-Silva, E.M.; Carvalho, K.S.; Bauer, M.O.; Cabral, C.H.A. Proporção de fertilizantes fosfatados no cultivo de forrageiras tropical em casa de vegetação. Revista de la Facultad de Agronomía, v.114, n.2, p.193-200, 2015. http://sedici.unlp.edu.ar/bitstream/handle/10915/51295/ Documento_completo.pdf-PDFA.pdf?sequence=1. 09 Sep. 2019.

Carneiro, J.S.S.; Silva, P.S.S.; Santos, A.C.M.; Freitas, G.A.; Silva, R.R. Resposta do capim Mombaça sob efeito de fontes e doses de fósforo na adubação de formação. Journal of Bioenergy and Food Science, v.4, n.1, p.12-25, 2017. https://doi.org/10.18067/ jbfs.v4i1.117.

Cherubin, M.R.; Fabris, C.; Weirich, S.W.; Rocha, E.M.T.; Basso, C.J.; Santi, A.L.; Lamego, F.P. Desempenho agronômico do milho em sucessão a espécies de cobertura do solo sob sistema plantio direto no Sul do Brasil. Global Science and Technology, v.7, n.1, p.76-85, 2014. https://doi.org/10.14688/1984-3801/gst.v7n1p76-85.

Costa, N.L.; Jank, L.; Magalhães, J.A.; Fogaça, F.H.; Rodrigues, A.N.A.; Santos, F.J.S. Acúmulo de forragem e morfogênese de Megathyrsus maximus cv. Mombaça sob níveis de fósforo. PUBVET, v.11, n.11, p.1163-1168, 2017. https://doi. org/10.22256/pubvet.v11n11.1163-1168.

Cruz, S.J.S.; Oliveira, S.C.; Cruz, S.C.S.; Machado, C.G.; Pereira, R.G. Adubação fosfatada para a cultura do sorgo granífero. Revista Caatinga, v.22, n.1, p.91-97, 2009. https://periodicos.ufersa.edu. br/index.php/caatinga/article/view/959/513. 16 Apr. 2020.

Dias, L.P.R.; Gatiboni, L.C.; Brunetto, G.; Arruda, B.; Costa, M.M. Distribuição e morfologia do sistema radicular de Eucalyptus dunnii em resposta à aplicação de fósforo. Revista de Ciências Agroveterinárias, v.16, n.3, p.203-213, 2017. https://doi. org/10.5965/223811711632017203.

Dias-Filho, M.B. Diagnóstico das pastagens no Brasil. 1.ed. Belém: Embrapa Amazônia Oriental, 2014. 36p. (Embrapa Amazônia Oriental. Documentos, 402).

Duchini, P.G.; Guzatti, G.C.; Ribeiro Filho, H.; Sbrissia, A.F. Intercropping black oat (Avena strigosa) and annual ryegrass (Lolium multiflorum) can increase pasture leaf production compared with their monocultures. Crop and Pasture Science, v.67, n.5, p.574-581, 2016. https://doi.org/10.1071/CP15170.

Fontaneli, R.S.; Santos, H.P.; Fontaneli, R.S. Forrageiras para integração lavoura-pecuária-floresta na região sul-brasileira. 2.ed. Brasília: Embrapa, 2012. 544p.

Jat, R.K.; Patel, A.G.; Shviran, A.; Bijarnia, A.L.; Bhunwal, V. Response of oat (Avena sativa $\mathrm{L}$.) on quality and economics to nitrogen and phosphorus levels under North Gujarat agro-climatic conditions. Journal of Crop and Weed, v.10, n.2, p.492-494, 2014. http:// www.cropandweed.com/archives/2014/vol10issue2/80.pdf. 18 Mar. 2020.

Joshi, R.V.; Patel, B.J.; Patel, K.M. Effect of nitrogen levels and time of application on growth, yield, quality, nitrogen, phosphorus content and uptake for seed production of oat (Avena sativa L.). Forage Research, v.41, n.2, p. 104-108, 2015. http:// forageresearch.in/wp-content/uploads/2015/11/104-108.pdf. 29 Mar. 2020. 
Long, S.R.; Kahn, M.; Seefeldt, L.; Tsay, Y-F.; Kopriva, S. Nitrogen and sulfur. In: Buchanan, B.B.; Gruissem, W. Jones, R.L. (Eds.). Biochemistry \& Molecular Biology of Plants. 2.ed. Hoboken: John Wiley \& Sons, 2015. Chap. 16, p.711-768.

Luikham, E.; Rolling Anal, P.S.; Mariam Anal, P.S. Effect of phosphorus and potash on yield, quality and economics of oat fodder (Avena sativa L.). Agricultural Science Digest, v.35, n.2, p.161-162, 2015. https://doi.org/10.5958/0976-0547.2015.00031.2.

Manarin, S.A. Combinações de doses de fosforo e de zinco em solução nutritiva para o Capim-Tanzânia. Piracicaba: Escola Superior de Agricultura Luiz de Queiroz, 2005. 68p. Master's Dissertation. http://www.teses.usp.br/teses/disponiveis/11/11140/tde09092005-154857. 19 Mar. 2020.

Maranguit, D.; Guillaume, T.; Kuzyakov, Y. Land-use change affects phosphorus fractions in highly weathered tropical soils. Catena, v. 149, part 1, p. 385-393, 2017. https://doi.org/10.1016/j. catena.2016.10.010.

Melo, M.P.; Lima, R.C.P.; Freitas, G.A.; Lima, S.O. Fontes e doses de fósforo na produção de Panicum maximum cv. Massai. Tecnologia \& Ciência Agropecuária, v.12, n.2, p.25-35, 2018. http:// revistatca.pb.gov.br/edicoes/volume-12-2018/volume-12-n-22018/04-ce-0218-06-fontes-e-doses-de-fosforo-na-producaode-panicum-maximum.pdf. 10 Mar. 2020.

Nakagawa, J.; Rosolem, C.A. Teores de nutrientes na folha e nos grãos de aveia-preta em função da adubação com fósforo e potássio. Revista Bragantia, v.64, n.3, p.441-445, 2005. https:// doi.org/10.1590/S0006-87052005000300014.

Oliveira, J.R.; Koetz, M.; Bonfim-Silva, E.M.; Silva, T.J.A. Production and accumulation of silicon (Si) in rice plants under silicate fertilization and soil water tensions. Australian Journal of Crop Science, v.10, n.2, p.244-250, 2016. http://www.cropj.com/ oliveira_10_2_2016_244_250.pdf. 27 Mar. 2020.

Ono, F.B.; Montagna, J.; Novelino, J.O.; Serafim, M.E.; Dallasta, D.C.; Garbiate, M.V. Eficiência agronômica de superfosfato triplo e fosfato natural de Arad em cultivos sucessivos de soja e milho. Ciência e Agrotecnologia, v.33, n.3, p.727-734, 2009. https://doi. org/10.1590/S1413-70542009000300010.

Parreira, L.H.M.; Martins, M.E.P.; Ribeiro, M.M.; Sena-Júnior J.M. Efeito da bactéria Azospirillum brasilense na adubação química e orgânica em pastagens constituídas de Brachiaria brizantha cv. Marandu. Enciclopédia Biosfera, v.11, n.21, p.838-850, 2015. https://doi.org/10.30945/rcr-v21i2.2707.

Pereira, L.E.T.; Nishida, N.T.; Carvalho, L.R.; Herling, V.R. Recomendações para correção e adubação de pastagens tropicais. Pirassununga: Faculdade de Zootecnia e Engenharia de Alimentos da USP, 2018. 56p.
Pimentel, R.M.; Bayão, G.F.V.; Lelis, D.L.; Cardoso, A.J.S.; Saldarriaga, F.V.; Melo, C.C.V.; Souza, F.B.M.; Pimentel, A.C.S.; Fonseca, D.M.; Santos, M.E.R. Ecofisiologia de plantas forrageiras. PUBVET, v.10, n.9, p.666-679, 2016. https://doi.org/10.22256/pubvet. v10n9.666-679.

Prado, R.M.; Romualdo, L.M.; Vale, D.W. Resposta da aveia preta à aplicação de fósforo sob duas doses de nitrogênio em condições de casa-de-vegetação. Acta Scientiarum. Agronomy, v.28, n.4, p.527-533, 2006. https://doi.org/10.4025/actasciagron.v28i4.895.

Prates, E.R. Técnicas de pesquisa em nutrição animal. Porto Alegre: Ed. UFRGS, 2007. 414p.

Primavesi, A.; Primavesi, A.M. A biocenose do solo na produção vegetal \& deficiências minerais em culturas. 1.ed. São Paulo: Expressão Popular, 2018. 608p.

Primavesi, A.C.; Rodrigues, A.A.; Godoy, R. Recomendações técnicas para o cultivo de aveia. 1.ed. São Carlos: Embrapa Pecuária Sudeste, 2000. 39p. (Embrapa Pecuária Sudeste. Boletim de Pesquisa, 6)

Rezende, A.V.; Lima, J.F.; Rabelo, C.H.S.; Rabelo, F.H.S.; Nogueira, D.A.; Carvalho, M.; Faria Junior, D.C.G.; Barbosa, L.A. Características morfofisiológicas da Brachiaria brizantha cv. Marandu em resposta à adubação fosfatada. Revista Agrarian, v.4, n.14, p.335-343, 2011. http://ojs.ufgd.edu.br/index.php/agrarian/article/view/1145/926 23 Mar. 2020

Saldanha, E.C.M.; Rocha, M.E.L. da; Araújo, J.L.S. de; Alves, J.D.N.; Mariano, D. de C.; Okumura, R.S. Adubação fosfatada na cultura do milho no nordeste paraense. Revista de Ciências Agroveterinárias, v.16, n.4, p.441-448, 2017. https://doi. org/10.5965/223811711642017441.

Santos, I.P.A. Morfofisiologia e valor nutritivo de gramíneas forrageiras tropicais sob fontes e doses de fósforo. Lavras: Universidade Federal de Lavras, 2004. 141p. Doctoral Thesis. http://repositorio. ufla.br/jspui/handle/1/4260. 09 Apr. 2020.

Silva, E.C.; Muraoka, T.; Villanueva, F.C.A.; Espinal, F.S.C. Aproveitamento de nitrogênio pelo milho, em razão da adubação verde, nitrogenada e fosfatada. Pesquisa Agropecuária Brasileira, v.44, n.2, p.118-127, 2009. https://doi.org/10.1590/S0100-204X2009000200002.

Taiz, L.; Zeiger, E.; Moller, I.; Murphy, A. Fisiologia e desenvolvimento vegetal. 6.ed. Porto Alegre: Artmed, 2017. 888p.

Wolff, W.M.; Floss, E.L. Correlação entre teores de nitrogênio e de clorofila na folha com o rendimento de grãos de aveia branca. Ciência Rural, v.38, n.6, p.1510-1515, 2008. https://doi. org/10.1590/s0103-84782008000600003.

Zamarchi, G.; Pavinato, P.S.; Menezes, L.F.G.; Martin, T.N. Silage of white oat under nitrogen fertilization and pre-wilting. Semina: Ciências Agrárias, v.35, n.4, p.2185-2196, 2014. https://doi. org/10.5433/1679-0359.2014v35n4p2185. 